\title{
AAV mediated delivery of a novel anti-BACE1 VHH reduces Abeta in an Alzheimer's disease mouse model
}

Melvin Y. Rincon ${ }^{1,2^{*}}$, Lujia Zhou ${ }^{1,2^{*}}$, Catherine Marneffe ${ }^{1,2}$, Iryna Voytyuk ${ }^{1,2}$, Yessica Wouters $^{1,2}$, Maarten Dewilde ${ }^{1,2}$, Sandra I. Duqué ${ }^{1,2}$, Cécile Vincke ${ }^{3}$, Yona Levites ${ }^{4}$, Todd E. Golde $^{4}$, Serge Muyldermans ${ }^{3}$, Bart De Strooper ${ }^{1,2,5,6}$, Matthew G. Holt ${ }^{1,2,6} \uparrow$.

${ }^{1}$ VIB-KU Leuven Center for Brain \& Disease Research, 3000 Leuven, Belgium.

${ }^{2}$ Department of Neurosciences, KU Leuven, 3000 Leuven, Belgium.

${ }^{3}$ Laboratory of Cellular and Molecular Immunology, Vrije Universiteit Brussel, Pleinlaan 2, 1050 Brussels, Belgium.

${ }^{4}$ Department of Neuroscience, Center for Translational Research in Neurodegenerative Disease, McKnight Brain Institute, College of Medicine, University of Florida, Gainesville, Florida, 32610-0159, USA.

${ }^{5}$ UK Dementia Research institute at UCL, Cruciform Building Gower Street WC1E 6BT, London. UK

${ }^{6}$ Leuven Brain Institute, 3000 Leuven, Belgium.

*These authors contributed equally to this work

\section{$\dagger$ Corresponding author:}

Dr. Matthew G. Holt

Laboratory of Glia Biology

VIB-KU Leuven Center for Brain and Disease Research

KU Leuven Department of Neuroscience

O\&N IV, Herestraat 49 - box 602, 3000 Leuven, Belgium

E-Mail: Matthew.Holt@kuleuven.vib.be

Phone: +32 163731 27: Fax: +32 16372700 
bioRxiv preprint first posted online Jul. 13, 2019; doi: http://dx.doi.org/10.1101/698506. The copyright holder for this preprint

(which was not peer-reviewed) is the author/funder, who has granted bioRxiv a license to display the preprint in perpetuity.

It is made available under a CC-BY-NC-ND 4.0 International license.

Anti-BACE1 VHH lowers $A \beta$ in an AD model

\begin{abstract}
Single domain antibodies ( $\mathrm{VHH})$ are potentially disruptive therapeutics, with important biological value for treatment of several diseases, including neurological disorders. However, VHH have not been widely used in the central nervous system (CNS), as it is hard to reach therapeutic levels, both because of their restricted blood-brain-barrier penetration and their apparent rapid clearance from the parenchyma. Here, we propose a gene transfer strategy based on adeno-associated virus (AAV)-based vectors to deliver $\mathrm{VHH}$ directly into the CNS, ensuring continuous production at therapeutic levels. As a proof-of-concept, we explored the potential of AAV-delivered VHH to inhibit BACE1, a well-characterized target in Alzheimer's disease. First, we generated a panel of VHHs targeting BACE1. One of them, VHH-B9, showed high selectivity for BACE1 and efficacy in lowering BACE1 activity in vitro. We then went on to demonstrate significant reductions in amyloid beta $(\mathrm{A} \beta)$ levels after AAV-based delivery of VHH-B9 into the CNS of a mouse model of cerebral amyloidosis. These results constitute a novel therapeutic approach for neurodegenerative diseases, which is applicable to a range of CNS disease targets.
\end{abstract}


bioRxiv preprint first posted online Jul. 13, 2019; doi: http://dx.doi.org/10.1101/698506. The copyright holder for this preprint

\section{INTRODUCTION}

The high selectivity of monoclonal antibodies (mAbs) offers unique opportunities to target key proteins involved in the etiology of neurodegenerative conditions, such as Parkinson's disease and Alzheimer's disease (AD) (Zhou et al, 2011; Panza et al, 2014). However, their potential as central nervous system (CNS) therapeutics is largely limited by their inability to cross the blood brain barrier (BBB) (Zafir-Lavie et al, 2018), comparatively poor biodistribution through the parenchyma (Freskgård \& Urich, 2017), and short half-life (Wang et al, 2018). In addition, there is the potential for Fc receptor-mediated immunogenicity, mediated by microglia, which can cause vasogenic edema and cerebral microhemorrhage (Panza et al, 2014).

Single variable domain antibodies (VHHs) are increasingly seen as an alternative to mAbs for therapeutic use (Steeland et al, 2016; Bannas et al, 2017; Gomes et al, 2018). In fact, the VHHbased therapeutic Cablivi ${ }^{\circledR}$ (caplacizumab-yhdp), was recently approved for market by the US Food and Drug Administration (Scully et al, 2019) for peripheral treatment of adults with acquired Thrombotic Thrombocytopenic Purpura (aTTP)

One key reason for their attractiveness over conventional mAbs is their small antigen binding site, which allows them to access unique epitopes not available to conventional mAbs, such as enzyme active sites, which are often key drug targets (Hassanzadeh-Ghassabeh et al, 2013). In addition, $\mathrm{VHH}$ have a much lower immunogenic profile than traditional $\mathrm{mAbs}$, largely due to the lack of an Fc-region.

Although there have been reports that VHH can pass through the BBB (Li et al, 2016), the degree of penetration is variable and linked to the intrinsic charge on the protein (Bélanger et $a l, 2019)$. Unfortunately, the amount reaching the CNS, following peripheral injection, is further compromised by their high rate of peripheral clearance, due to renal excretion (Gainkam et al, 2008; Bannas et al, 2015). Although VHHs which do actually reach the CNS (or are directly injected into the CNS) typically have a longer half-life than in plasma, detectable levels are still reduced by up to $50 \%$ twenty-four hours post-injection (Dorresteijn et al, 2015). Genetic delivery of therapeutic VHHs, directly to the CNS, offers a potential solution to these issues, allowing long-term local production (Zafir-Lavie et al, 2018).

Adeno-associated virus (AAV)-based vectors are becoming the vehicle of choice for gene therapy applications, due to their high efficiency of gene transfer and excellent safety profile (reviewed extensively in Hudry \& Vandenberghe, 2019). The major drawback of AAV vectors is the limited cargo capacity: transgenes larger than $5 \mathrm{~kb}$ in size are not efficiently packed into the vector (Trapani et al, 2014). Therefore, VHH are ideal candidates for AAV-mediated delivery, as they are comparatively small (typically 350 bp in size) and can be easily 
bioRxiv preprint first posted online Jul. 13, 2019; doi: http://dx.doi.org/10.1101/698506. The copyright holder for this preprint

incorporated into AAV vectors without extensive modifications that can adversely affect their binding properties (Pain et al, 2015), which is a common issue with AAV-mediated delivery of mAbs (Wu et al, 2010). In theory, it also allows for additional engineering, for example, directing the $\mathrm{VHH}$ into specific trafficking pathways to improve target engagement (Dmitriev et al, 2016), or incorporating specific proteolysis-promoting sequences to stimulate intracellular degradation of toxic species (Baudisch et al, 2018).

In this work, we describe an efficient AAV-based system for delivery of therapeutic VHH into the CNS. As a proof-of-concept strategy, we targeted the $\beta$-site amyloid precursor proteincleaving enzyme 1 (BACE1), which is a key component in amyloid beta peptide (A $\beta)$ production in AD (Vassar et al, 1999; Cai et al, 2001). In a two-stage process, we first generated a novel $\mathrm{VHH}$, named B9, which effectively inhibits BACE1 in vitro. In the second phase, we then used an AAV vector to deliver B9 into the CNS of an AD mouse model, producing a long-term reduction in $\mathrm{A} \beta$ production after a single injection. Together, our results demonstrate that $\mathrm{VHH}$ against key CNS disease targets can be produced and delivered efficiently using gene therapy vectors. This approach constitutes a unique therapeutic avenue, not only for AD but for the broad spectrum of CNS diseases.

\section{RESULTS}

\section{Production and identification of anti-BACE1 VHH}

To generate VHH, a dromedary and a llama were immunized with purified human BACE1 ectodomain (amino acids 46-460) (Figure 1A). In total, 16 different clones were identified that bind to BACE1.

\section{Identification of VHH inhibiting BACE1}

We screened for a possible effect of $\mathrm{VHH}$ on enzyme activity employing an in vitro APP cleavage assay (Zhou et al, 2011). Sixteen VHHs were recombinantly expressed in bacteria, purified and added to the assay at a final concentration of $5 \mu \mathrm{M}$. VHH inhibited BACE1 to varying degrees, with three VHH consistently giving the highest level of inhibition, with halfmaximal effective concentrations $\left(\mathrm{EC}_{50}\right)$ in the nanomolar range: $99.2 \mathrm{nM}$ (VHH-B9), 112.5 $\mathrm{nM}$ (VHH-10C4) and 788.7 nM (VHH-4A2) (Figure 1B, C; Appendix Figure S1).

\section{Characterization of VHH-BACE1 binding}

More detailed examination of VHH-BACE1 binding was obtained using the surface plasmon resonance (SPR) technique. The equilibrium dissociation constant $\left(\mathrm{K}_{\mathrm{D}}\right)$ was determined for VHH-B9, VHH-10C4 and VHH-4A2 at both $\mathrm{pH} 7.0$ (representing the $\mathrm{pH}$ of the extracellular environment) and $\mathrm{pH} 4.5$ (pH of the endosomal compartment). In both cases, VHH-B9 showed the highest affinity to BACE1 (Figure 1D). Interestingly, binding affinity seemed to be slightly 
bioRxiv preprint first posted online Jul. 13, 2019; doi: http://dx.doi.org/10.1101/698506. The copyright holder for this preprint

stronger at $\mathrm{pH} 4.5$, which is beneficial, as the majority of APP cleavage is reported to occur in the endosomal system (Sannerud et al, 2011; Ben Halima et al, 2016). Despite the high binding affinity of VHH-B9 towards human and mouse BACE1, it did not show any binding to mouse BACE2 under the same measurement conditions (Figure 1E), indicating a high degree of selectivity. Based on these results, VHH-B9 was chosen as the principal candidate for further characterization and testing.

We also explored the epitope on BACE1 mediating VHH-B9 binding by performing competition assays with the well-characterized monoclonal antibody 1A11 (Zhou et al, 2011). 1A11 was able to compete for BACE1 binding with VHH-B9 suggesting that these two antibodies bind to overlapping epitopes (Appendix Figure S2). The identity of the epitope was established by observing the binding of VHH-B9 to a series of BACE1 mutants in a dot blot assay. Our results suggest that VHH-B9 binds to BACE1 at Helix A and Loop F, which are close to the active site of the enzyme (Appendix Figure S3). Thus, VHH-B9 may act by blocking effective substrate entry

\section{VHH-B9 effectively inhibits neuronal BACE1 in primary neuronal cultures}

To test if VHH-B9 inhibits the enzyme in its native membrane environment, we turned to primary neuronal cultures. Cells were transduced by Semliki Forest Virus (SFV) expressing wild type human $\mathrm{APP}_{695}$ and then treated for 12 hours with recombinant VHH-B9 at a final concentration of $3 \mu \mathrm{M}$. Treatment with $\mathrm{VHH}-\mathrm{B} 9$ decreased the levels of $\mathrm{sAPP}_{\beta}, \mathrm{CTF}_{\beta}, \mathrm{A} \beta_{1-40}$ and $A \beta_{1-42}$ detected. The levels of full-length APP, however, remained unchanged (Figure $2 \mathrm{~A}$, $\mathrm{B}, \mathrm{C})$. VHH-B9 inhibits BACE1 in a dose dependent manner (Figure 2D), with an $\mathrm{EC}_{50}(95 \%$ confidence interval) of $85.4 \mathrm{nM}(52.5 \mathrm{nM}$ to $125.6 \mathrm{nM})$ (Figure 2E). Together, these results indicate that VHH-B9 inhibits BACE1 activity in a native neuronal environment. Note that VHH-10C4 and VHH-4A2 were also tested in neuronal cultures. While both these VHHs inhibited BACE1 activity, VHH-B9 was the most effective, as predicted from the in vitro assays (Figure 1).

We next investigated the relative levels of BACE1-mediated cleavage of known substrates following treatment with VHH-B9 (Figure 2F, G). For these experiments, the cDNA for VHHB9 was modified to contain an N-terminal BACE1 signal peptide and a C-terminal cMyc tag. This cDNA sequence was then cloned into a single-stranded AAV expression cassette and packaged into an AAV capsid (AAV-VHH-B9) (Fripont et al, 2019), which was used to transduce primary neuronal cultures. The non-selective BACE1 and BACE2 inhibitor Compound $\mathrm{J}(\mathrm{CpJ})$ (Esterházy et al, 2011) was used as a positive control. Blocking of sAPP $\beta$ shedding was observed in neurons upon transduction with AAV-VHH-B9 or $\mathrm{CpJ}$ treatment. In contrast, shedding of seizure protein 6 (SEZ6), a well-known neuronal substrate of BACE1 
bioRxiv preprint first posted online Jul. 13, 2019; doi: http://dx.doi.org/10.1101/698506. The copyright holder for this preprint

(Pigoni et al, 2016), was only inhibited by $\mathrm{CpJ}$ and remained unaffected by VHH-B9 (Figure 1F). Next, using primary glial cultures we evaluated the effects of VHH-B9 on BACE2 by assessing the cleavage of two known substrates, Delta and Notch-like epidermal growth factorrelated receptor (DNER) and Vascular cell adhesion molecule 1 (VCAM1) (Voytyuk et al, 2018b). As expected from our previous binding data (Figure 1E), the shedding of both DNER and VCAM1 was unaffected after transduction with AAV-VHH-B9, whereas CpJ efficiently blocked the shedding of both substrates (Figure 2G).

Viral vector mediated delivery of $V H H-B 9$ reduced A $\beta$ levels in a mouse model of amyloidosis. We next attempted to reduce $\mathrm{A} \beta$ production in vivo using AAV-based delivery of VHH-B9. In these experiments, an AAV vector encoding GFP was produced for use as a control. AAV vectors were tested in the APPDutch mouse model of cerebral amyloidosis. This is a transgenic line with neuronal overexpression of human E693Q APP, which causes hereditary cerebral hemorrhage with Dutch type amyloidosis. APPDutch mice present an increased $A \beta_{1-40 / 42}$ ratio from an early age (Herzig et al., 2004). Hence, we evaluated the activity of VHH-B9 by direct delivery of AAV-VHH-B9 $(\mathrm{n}=10)$ or AAV-GFP (control, $\mathrm{n}=11$ ) vectors in six-weeks-old mice using a bilateral injection of $2 \times 10^{10}$ vector genomes $(\mathrm{vg})$ per injection site (Appendix Figure S4). Three weeks post-delivery, mice were euthanized. In animals showing VHH-B9 expression, colocalization of VHH-B9 with BACE1 was observed (Figure 3A-D), suggesting significant target engagement. ELISA measurements showed that $\mathrm{VHH}-\mathrm{B} 9$ expression led to a significant decrease in levels of both $A \beta_{1-40}$ and $A \beta_{1-42}$ (Figure 3E, F), indicative of BACE1 inhibition. No apparent toxicity, derived from either the VHH or the vector, was observed, either on animal survival rates, or at the histological level post-mortem (data not shown).

\section{DISCUSSION}

We exploited the known strengths of the VHH platform to successfully demonstrate targeting of BACE1, an important CNS target central to AD pathology (Vassar et al, 1999; Barão et al, 2016; Voytyuk et al, 2018b). These strengths include the ability to rapidly and easily identify VHHs that specifically bind the intended target with adequate affinity, under physiological conditions (Steeland et al, 2016). Furthermore, by exploiting the high intrinsic stability of VHHs and ease of engineering (Vincke et al, 2009), we were able to incorporate a signal peptide into the $\mathrm{VHH}$ sequence, allowing intracellular expression and directed trafficking to the endosome, where the majority of BACE1-mediated APP cleavage is thought to occur (Sannerud et al, 2011; Ben Halima et al, 2016). This was done with the aim of promoting VHH-BACE1 interactions early in the secretory pathway, which may be beneficial as some mutations in APP, such as the Swedish mutation (Swe), are known to promote processing of APP in the secretory pathway itself (Sasaguri et al, 2017). Finally, the small size of VHH allowed easy incorporation into an AAV-based vector (Verhelle et al, 2017). Use of such a 
bioRxiv preprint first posted online Jul. 13, 2019; doi: http://dx.doi.org/10.1101/698506. The copyright holder for this preprint

system facilitated intracellular delivery and continuous VHH expression, with direct parenchymal injection circumventing the shielding effect of the BBB, which has often limited the therapeutic efficiency of antibody therapies for brain disorders (Barão et al, 2016). This allowed us to achieve long-term reductions in BACE1 activity and $\mathrm{A} \beta$ production in a mouse model of Alzheimer's type amyloidosis.

As BACE1 contributes to $80 \%$ of $A \beta_{1-40}$ production in the brain (Atwal et al, 2011). The decreases in steady state $A \beta$ levels that we report here are significant, especially considering they were achieved after a single administration of vector. By way of comparison, a single intracisternal injection of $75 \mu \mathrm{g}$ VHH-B3a in APPswe/PS1dE9 mice (Dorresteijn et al, 2015) showed no significant decrease in the level of soluble $A \beta_{1-40}$ twenty-four hours post-injection. This presumably reflects the relative high dissociation constant of this VHH for BACE1 (0.3 $\mu \mathrm{M}$ ), a gradual decrease in available VHH (possibly as a result of clearance), or a combination of both factors. In contrast, direct injections of conventional mAbs, or systemic administration of mAbs engineered to cross the $\mathrm{BBB}$ by receptor-mediated transcytosis, led to BACE1 inhibition in a dose-dependent fashion (Zhou et al, 2011; Cheng et al, 2013; Ye et al, 2017). In these examples, however, effective inhibition was typically limited to a period of up to fortyeight hours post-injection. Taken together, we believe these results largely validate our experimental strategy, although further work will be needed to determine the optimal temporal window for intervention in the disease process.

At present, the levels of $\mathrm{A} \beta$ decrease necessary to produce an effect in $\mathrm{AD}$ are undetermined (Kennedy et al, 2016; Timmers et al, 2018; Egan et al, 2019). However, there are reasons to believe that a sustained steady state reduction, similar to that which we report, may be worthwhile pursuing. First, a reduction of 50\% in the levels of BACE1 activity is sufficient to significantly reduce $A \beta$ plaques, neuritic burden, and synaptic deficits in mouse models of $A D$ (McConlogue et al, 2007), similar to the effects seen with a reduction of $30 \%$ in the levels of gamma secretase activity (Li et al, 2007). Second, a mutation in human APP, which reduces cleavage by BACE1 (Jonsson et al, 2012), leads to a reduction in cerebral A $\beta$ of approximately $20 \%$, with carriers showing lifelong protection against $\mathrm{AD}$ and cognitive decline (although issues with the mutation affecting aggregation of $\mathrm{A} \beta$ peptides cannot be fully excluded) (Maloney et al, 2014; Benilova et al, 2014).

Sustained protection through low to moderate levels of CNS-localized BACE1-specific inhibition may well have the additional benefit of reducing, or avoiding, toxicity related to complete loss of BACE1 function, such as hypomyelination (Willem et al, 2006), aberrant synaptic homeostasis and plasticity (Filser et al, 2015), axon guidance abnormalities (Rajapaksha et al, 2011; Cao et al, 2012; Ou-Yang et al, 2018), impairments in spatial and 
bioRxiv preprint first posted online Jul. 13, 2019; doi: http://dx.doi.org/10.1101/698506. The copyright holder for this preprint

working memory (Henley et al, 2019; Knopman, 2019; Egan et al, 2019) and retinal pathology (Cai et al, 2012). In this respect, it is important to note that the levels of BACE1 inhibition achieved with AAV-mediated delivery of VHH-B9 did not substantially affect cleavage of the alternative BACE1 substrate seizure protein 6 (SEZ6), which is important for maintenance of dendritic spines and synaptic plasticity (Gunnersen et al, 2007; Pigoni et al, 2016; Zhu et al, 2018). This is most simply explained by the relative amounts of APP and SEZ6 available for cleavage in a mass-action model (Wilhelm et al, 2014). Peripheral effects of BACE1 inhibition on muscle spindle assembly, as well as cross-reactivity with BACE2, Cathepsin D and Cathepsin E, which can lead to impairments in glucose homeostasis, hypopigmentation, seizures and blindness (amongst others), are also avoided (Voytyuk et al, 2018b). Crucially, no signs of apparent toxicity from the $\mathrm{VHH}$ or viral vector (at the doses used) were observed over 4 weeks post-vector delivery, consistent with predictions on tolerability from other studies (LeWitt et al, 2011; Saraiva et al, 2016). Long-term studies focusing on these issues will, however, be essential to determine the clinical feasibility of this approach.

Additional experiments will also be needed to determine the effective therapeutic dose of AAV-VHH-B9 required and whether any reduction in total $A \beta$ load leads to improvements in cognitive function. However, if required, modifications to the system can easily be made by taking advantage of the relative ease with which VHH and AAV can be engineered. For example, VHH affinities in the low picomolar range can be achieved using standard affinity maturation techniques (Mahajan et al, 2018), or via production of bivalent VHH constructs (Beirnaert et al, 2017) that bind distinct epitopes on a given target. Expression levels of a given VHH from a vector-based system can be improved by use of a self-complementary genome configuration, containing multiple copies of the VHH coding sequence (Verhelle et al, 2017). Use of specific promoter systems, in combination with cell type specific transcriptional enhancers and inducible elements (Hudry \& Vandenberghe, 2019), should also allow temporally controllable and graded levels of VHH expression in cell types of interest. As demonstrated, VHH can be modified to add unique functions, such as signal peptide sequences (Vincke et al, 2009). This can be further exploited to include, for example, sequences targeting the VHH-antigen complex for degradation (Caussinus et al, 2011). The efficacy of such modifications, for example in reducing $A \beta$ levels, remains to be established. Finally, AAV vectors which cross the BBB at high efficiency and achieve widespread CNS transduction are being developed. These AAV vectors show considerable promise for delivery of therapeutics to the CNS following systemic injection, removing the need for invasive direct intraparenchymal injections or cerebrospinal fluid-based injections, whilst facilitating broad transgene delivery (Deverman et al, 2016). In reality, it is likely to be a combination of technological developments in the aforementioned areas that finally makes AAV-mediated delivery of antibodies, or antibody fragments, a clinically relevant option for CNS disorders. 
bioRxiv preprint first posted online Jul. 13, 2019; doi: http://dx.doi.org/10.1101/698506. The copyright holder for this preprint

As production costs drop, such single use AAV technology is likely to offer a more costeffective alternative to regular infusions of recombinant antibodies or anti-sense oligonucleotides.

In summary, using the well characterized read out of BACE1inhibition as a proof-of-concept, we have shown the viability of combining VHH with viral vector-mediated delivery to target a specific CNS protein, producing local and statistically significant reduction in A $\beta$ levels, after a single injection. Moving forward, we propose that vector-mediated delivery of VHHs can be successfully exploited for the treatment of a variety of CNS conditions with defined targets, such as Parkinson's disease and amyotrophic lateral sclerosis, which are, at present, untreatable.

\section{FIGURE LEGENDS}

\section{Figure 1. Generation and in vitro characterization of anti-BACE1 VHH.}

A. Schematic summarizing the procedure used to generate anti-BACE1 VHHs. A dromedary and a llama were immunized with recombinant human BACE1 ectodomain (amino acids 46460). Blood lymphocytes from the immunized animals were collected for RNA extraction. cDNA was prepared and the variable fragments of heavy chain only IgGs were amplified by RT-PCR and purified using agarose gel electrophoresis. cDNAs encoding VHH were cloned into the pHEN4 phagemid vector and phage libraries were prepared. Three rounds of consecutive phage panning were performed to enrich phage particles that bound recombinant BACE1 in an ELISA assay. Binding to BACE1 was confirmed in a phage ELISA. Finally, BACE1 binding VHHs were purified and further characterized by the MBP-C125sw enzymatic assay.

B. VHHs inhibiting BACE1 were identified with an in vitro assay, which uses the maltose binding protein (MBP) fused to a fragment of human APP containing the Swedish mutation (APP amino acids 571-965: K670M/N671L) (MBP-C125APPsw assay). VHHs were recombinantly expressed in bacteria, purified and added to the assay at a final concentration of $5 \mu \mathrm{M}$. VHH-B9, VHH-10C4 and VHH-4A2 consistently inhibited BACE1 activity, compared to PBS or control VHH (A $\beta 3$ and BCIILP, raised against $\mathrm{A} \beta$ peptide and $\beta$-lactamase $\mathrm{BCII}$ $659 / \mathrm{H}$, respectively). Values are mean \pm range, $n=2$.

C. Dose-response curves for anti-BACE1 VHHs in the MBP-C125APPsw enzymatic assay. The $\mathrm{EC}_{50}$ values (95\% confidence interval) for VHH-B9, VHH-10C4 and VHH-4A2 are 99.2 $\mathrm{nM}(83.8-117.5 \mathrm{nM}), 112.5 \mathrm{nM}(101.1-125.2 \mathrm{nM})$ and $788.7 \mathrm{nM}(682.7-911.2 \mathrm{nM})$, respectively. Values are mean \pm S.D., $n=3$.

D. Binding affinities of selected VHHs for BACE1. Measurements were made on a BIAcore instrument, using purified BACE1 ectodomain coupled to a CM5 chip. Binding constants were calculated at both $\mathrm{pH} 7.0$ and $\mathrm{pH} 4.5$ to confirm that the selected VHHs bind BACE1 under physiological conditions (extracellular space or trafficking endosome, respectively). 
bioRxiv preprint first posted online Jul. 13, 2019; doi: http://dx.doi.org/10.1101/698506. The copyright holder for this preprint

E. Binding affinities of VHH-B9 for BACE1 and BACE2.

Figure 2. Specific inhibition of BACE1-mediated APP cleavage in primary neuronal cultures using VHH.

A, B, C. Primary cultured neurons were transduced by Semliki Forest virus (SFV) expressing wild type human APP695 and treated with $3 \mu \mathrm{M}$ of the indicated VHHs. PBS and anti-GFP VHH were used as controls. (A) Western blot analysis of conditioned media for sAPP $\alpha$ and sAPP $\beta$, as well as cell extracts for full length APP, CTF $\alpha$ and CTF $\beta$. (B) ELISA measurement of $A \beta_{1-40}$ in conditioned media. (C) ELISA measurement of $A \beta_{1-42}$ in conditioned media. Values are mean \pm S.E.M., $n=3$ cultures for each analysis. One-way ANOVA, $* * * p<0.0001$, $* * \mathrm{p}<0.01, * \mathrm{p}<0.5$.

D, E. Dose-dependent inhibition of BACE1 in primary cultured neurons by VHH-B9. Cultured neurons were transduced by SFV expressing wild type human APP695 and treated with PBS (control: CT) or decreasing concentrations of VHH-B9, ranging from $10 \mu \mathrm{M}$ to $0.7 \mathrm{nM}$. (D) Western blot analysis of conditioned media for sAPP $\alpha$ and $\operatorname{APP} \beta$, as well as cell extracts for full length APP, CTF $\alpha$ and CTF $\beta$. (E) Conditioned media was analyzed by ELISA to assess levels of $A \beta_{1-40}$. Values are mean \pm S.D., $n=3$ cultures for each analysis. The $E_{50}$ value $(95 \%$ confidence interval) was estimated as $85.4 \mathrm{nM}(52.5-125.6 \mathrm{nM})$.

F. Primary cultured neurons were transduced with an AAV vector driving the expression of VHH-B9. Compound J (CpJ) was used as control. VHH-B9 inhibited APP cleavage, as seen by a decrease in SAPP $\beta$ production. However, no decrease in SEZ6 shedding was observed. In contrast CpJ successfully inhibited both APP and SEZ6 shedding. Actin was used as a loading control. Anti-cMyc tag and anti-llama IgG were used for $\mathrm{VHH}$ detection. $\mathrm{n}=3$ cultures for each analysis.

G. Primary cultured glia were transduced with an AAV vector driving the expression of VHHB9, or treated with CpJ. VHH-B9 had no effect on the cleavage of the BACE2 substrates DNER and VCAM1. CpJ effectively blocked shedding of both substrates. $n=3$ cultures for each analysis.

Figure 3. Long-term BACE1 inhibition in APPDutch mice after AAV-VHH delivery significantly reduces amyloid beta load.

A-D. AAV-VHH-B9 vector was injected into the hippocampus of APPDutch mice $(n=3)$ at a dose of $2 \times 10^{10} \mathrm{vg}$ per site. Three weeks post-injection, brains were recovered and processed for immunohistochemistry. Representative images of coronal brain sections are shown for staining against BACE1 (magenta) and cMyc (green). Images show colocalization of VHH-B9 with BACE1 in the pyramidal cell layer (Pyr), as well as in the suprapyramidal blade (SPB) and infrapyramidal blade (IPB) of the mossy fibers. The diffuse staining patterns suggest that 
bioRxiv preprint first posted online Jul. 13, 2019; doi: http://dx.doi.org/10.1101/698506. The copyright holder for this preprint

VHH-B9 is engaged with BACE1 in internal structures, such as early endosomes. Scale bar, $25 \mu \mathrm{m}$.

E, F. APP Dutch mice were injected in the hippocampus with AAV-VHH-B9 $(n=11)$ or the control vector AAV-GFP $(\mathrm{n}=10)$. Whole brains were collected 3 weeks post-injection for analysis. Soluble protein was extracted and used for quantification of $A \beta_{1-40}$ and $A \beta_{1-42}$ levels by ELISA. VHH-B9 expression led to a significant decrease in both $A \beta_{1-40}(27.3 \%, p=0.0168)$ and $\mathrm{A} \beta_{1-42}(27.5 \%, \mathrm{p}=0.0026)$ levels.

\section{ACKNOWLEDGEMENTS}

Dr. Matthias Jucker kindly provided the APPDutch mouse model. MYR is a postdoctoral researcher with the FWO (133722/1204517N) and acknowledges the continuous support of the Fundación Cardiovascular de Colombia. SID was supported by The Foundation for Alzheimer Research (SAO-FRA) (P\#14006). MGH was supported by a VIB institutional grant and external support from the Thierry Latran Foundation (SOD-VIP), FWO (Grant 1513616N) and European Research Council (ERC) (Starting Grant 281961 - AstroFunc; Proof of Concept Grant 713755 - AD-VIP). Work in the BDS Lab is supported by the Opening the Future campaign of the KU Leuven, SAO-FRA (P\#16017), FWO, KU Leuven, VIB, a Methusalem grant from KU Leuven and the Flemish Government, the Flanders Network for Dementia Research (VIND, Strategic Basic Research Grant 135043) and the Alzheimer's Association. BDS is supported by the Geneeskundige Stichting Koningin Elisabeth and the Bax-Vanluffelen Chair for Alzheimer's disease. We want to thank the collaborators of the VIB Nanobody Core for their valuable contribution to the research presented in this paper.

\section{AUTHOR CONTRIBUTIONS}

BDS and MGH conceived the project. $\mathrm{LZ}, \mathrm{CV}, \mathrm{SM}, \mathrm{YW}, \mathrm{MD}$ and BDS generated and characterized the anti-BACE1 VHH. MYR generated the AAV used in tissue culture experiments; YL and TEG generated the AAV used for in vivo experiments. LZ, CM and IV performed tissue culture experiments. MYR and SID performed experiments with APPDutch mice. MYR, LZ, SID, BDS and MGH analyzed the data. MGH, MYR and LZ wrote the manuscript with input from all authors.

\section{CONFLICT OF INTEREST}

Johnson and Johnson provided antibodies used in this study. Eli Lilly provided reagents used in the peptide cleavage experiments. However, neither company played a role in the design and execution of the study, or the interpretation of results. BDS has acted as a consultant for Janssen Pharmaceutica and Remynd NV. The remaining authors declare no conflict of interest.

\section{REFERENCES}

Atwal JK, Chen Y, Chiu C, Mortensen DL, Meilandt WJ, Liu Y, Heise CE, Hoyte K, Luk W, 
bioRxiv preprint first posted online Jul. 13, 2019; doi: http://dx.doi.org/10.1101/698506. The copyright holder for this preprint

Lu Y, Peng K, Wu P, Rouge L, Zhang Y, Lazarus RA, Scearce-Levie K, Wang W, Wu Y, Tessier-Lavigne M \& Watts RJ (2011) A therapeutic antibody targeting BACE1 inhibits amyloid- $\beta$ production in vivo. Sci Transl Med 3: 84 ra43

Bannas P, Hambach J \& Koch-Nolte F (2017) Nanobodies and Nanobody-Based Human Heavy Chain Antibodies As Antitumor Therapeutics. Front Immunol 8: 1603

Bannas P, Lenz A, Kunick V, Fumey W, Rissiek B, Schmid J, Haag F, Leingärtner A, Trepel M, Adam G \& Koch-Nolte F (2015) Validation of nanobody and antibody based in vivo tumor xenograft NIRF-imaging experiments in mice using ex vivo flow cytometry and microscopy. J Vis Exp: e52462

Barão S, Moechars D, Lichtenthaler SF \& De Strooper B (2016) BACE1 Physiological Functions May Limit Its Use as Therapeutic Target for Alzheimer's Disease. Trends Neurosci. 39: $158-169$

Baudisch B, Pfort I, Sorge E \& Conrad U (2018) Nanobody-Directed Specific Degradation of Proteins by the 26S-Proteasome in Plants. Front Plant Sci 9: 130

Beirnaert E, Desmyter A, Spinelli S, Lauwereys M, Aarden L, Dreier T, Loris R, Silence K, Pollet C, Cambillau C \& de Haard H (2017) Bivalent Llama Single-Domain Antibody Fragments against Tumor Necrosis Factor Have Picomolar Potencies due to Intramolecular Interactions. Front Immunol 8: 867

Bélanger K, Iqbal U, Tanha J, MacKenzie R, Moreno M \& Stanimirovic D (2019) SingleDomain Antibodies as Therapeutic and Imaging Agents for the Treatment of CNS Diseases. Antibodies 8: 27

Ben Halima S, Mishra S, Raja KMP, Willem M, Baici A, Simons K, Brüstle O, Koch P, Haass C, Caflisch A \& Rajendran L (2016) Specific Inhibition of $\beta$-Secretase Processing of the Alzheimer Disease Amyloid Precursor Protein. Cell Rep 14: 2127-2141

Benilova I, Gallardo R, Ungureanu A-A, Castillo Cano V, Snellinx A, Ramakers M, Bartic C, Rousseau F, Schymkowitz J \& De Strooper B (2014) The Alzheimer disease protective mutation A2T modulates kinetic and thermodynamic properties of amyloid- $\beta$ (A $\beta$ ) aggregation. J. Biol. Chem. 289: 30977-30989

Cai H, Wang Y, McCarthy D, Wen H, Borchelt DR, Price DL \& Wong PC (2001) BACE1 is the major beta-secretase for generation of Abeta peptides by neurons. Nat. Neurosci. 4: 233234

Cai J, Qi X, Kociok N, Skosyrski S, Emilio A, Ruan Q, Han S, Liu L, Chen Z, Bowes Rickman C, Golde T, Grant MB, Saftig P, Serneels L, de Strooper B, Joussen AM \& Boulton ME (2012) $\beta$-Secretase (BACE1) inhibition causes retinal pathology by vascular dysregulation and 
bioRxiv preprint first posted online Jul. 13, 2019; doi: http://dx.doi.org/10.1101/698506. The copyright holder for this preprint

(which was not peer-reviewed) is the author/funder, who has granted bioRxiv a license to display the preprint in perpetuity.

It is made available under a CC-BY-NC-ND 4.0 International license.

accumulation of age pigment. EMBO Mol Med 4: 980-991

Cao L, Rickenbacher GT, Rodriguez S, Moulia TW \& Albers MW (2012) The precision of axon targeting of mouse olfactory sensory neurons requires the BACE1 protease. Sci Rep 2: 231

Caussinus E, Kanca O \& Affolter M (2011) Fluorescent fusion protein knockout mediated by anti-GFP nanobody. Nat. Struct. Mol. Biol. 19: 117-121

Cheng X, Zhou Y, Gu W, Wu J, Nie A, Cheng J, Zhou J, Zhou W \& Zhang Y (2013) The selective BACE1 inhibitor VIa reduces amyloid- $\beta$ production in cell and mouse models of Alzheimer's disease. J. Alzheimers Dis. 37: 823-834

Deverman BE, Pravdo PL, Simpson BP, Kumar SR, Chan KY, Banerjee A, Wu W-L, Yang B, Huber N, Pasca SP \& Gradinaru V (2016) Cre-dependent selection yields AAV variants for widespread gene transfer to the adult brain. Nat. Biotechnol. 34: 204-209

Dmitriev OY, Lutsenko S \& Muyldermans S (2016) Nanobodies as Probes for Protein Dynamics in Vitro and in Cells. J. Biol. Chem. 291: 3767-3775

Dorresteijn B, Rotman M, Faber D, Schravesande R, Suidgeest E, van der Weerd L, van der Maarel SM, Verrips CT \& El Khattabi M (2015) Camelid heavy chain only antibody fragment domain against $\beta$-site of amyloid precursor protein cleaving enzyme 1 inhibits $\beta$-secretase activity in vitro and in vivo. FEBS J. 282: 3618-3631

Egan MF, Kost J, Voss T, Mukai Y, Aisen PS, Cummings JL, Tariot PN, Vellas B, van Dyck CH, Boada M, Zhang Y, Li W, Furtek C, Mahoney E, Harper Mozley L, Mo Y, Sur C \& Michelson D (2019) Randomized Trial of Verubecestat for Prodromal Alzheimer's Disease. N. Engl. J. Med. 380: 1408-1420

Esterházy D, Stützer I, Wang H, Rechsteiner MP, Beauchamp J, Döbeli H, Hilpert H, Matile H, Prummer M, Schmidt A, Lieske N, Boehm B, Marselli L, Bosco D, Kerr-Conte J, Aebersold R, Spinas GA, Moch H, Migliorini C \& Stoffel M (2011) Bace2 Is a $\beta$ Cell-Enriched Protease that Regulates Pancreatic $\beta$ Cell Function and Mass. Cell Metabolism 14: 365-377

Filser S, Ovsepian SV, Masana M, Blazquez-Llorca L, Brandt Elvang A, Volbracht C, Müller MB, Jung CKE \& Herms J (2015) Pharmacological inhibition of BACE1 impairs synaptic plasticity and cognitive functions. Biol. Psychiatry 77: 729-739

Freskgård P-O \& Urich E (2017) Antibody therapies in CNS diseases. Neuropharmacology 120: $38-55$

Fripont S, Marneffe C, Marino M, Rincon MY \& Holt MG (2019) Production, Purification, and Quality Control for Adeno-associated Virus-based Vectors. J Vis Exp 
bioRxiv preprint first posted online Jul. 13, 2019; doi: http://dx.doi.org/10.1101/698506. The copyright holder for this preprint

Gainkam LOT, Huang L, Caveliers V, Keyaerts M, Hernot S, Vaneycken I, Vanhove C, Revets H, De Baetselier P \& Lahoutte T (2008) Comparison of the biodistribution and tumor targeting of two $99 \mathrm{mTc}$-labeled anti-EGFR nanobodies in mice, using pinhole SPECT/micro-CT. $J$. Nucl. Med. 49: 788-795

Gomes JR, Cabrito I, Soares HR, Costelha S, Teixeira A, Wittelsberger A, Stortelers C, Vanlandschoot P \& Saraiva MJ (2018) Delivery of an anti-transthyretin Nanobody to the brain through intranasal administration reveals transthyretin expression and secretion by motor neurons. J. Neurochem. 145: 393-408

Gunnersen JM, Kim MH, Fuller SJ, De Silva M, Britto JM, Hammond VE, Davies PJ, Petrou S, Faber ESL, Sah P \& Tan S-S (2007) Sez-6 proteins affect dendritic arborization patterns and excitability of cortical pyramidal neurons. Neuron 56: 621-639

Hassanzadeh-Ghassabeh G, Devoogdt N, De Pauw P, Vincke C \& Muyldermans S (2013) Nanobodies and their potential applications. Nanomedicine (Lond) 8: 1013-1026

Henley D, Raghavan N, Sperling R, Aisen P, Raman R \& Romano G (2019) Preliminary Results of a Trial of Atabecestat in Preclinical Alzheimer's Disease. N. Engl. J. Med. 380: $1483-1485$

Hudry E \& Vandenberghe LH (2019) Therapeutic AAV Gene Transfer to the Nervous System: A Clinical Reality. Neuron 101: 839-862

Jonsson T, Atwal JK, Steinberg S, Snaedal J, Jonsson PV, Bjornsson S, Stefansson H, Sulem P, Gudbjartsson D, Maloney J, Hoyte K, Gustafson A, Liu Y, Lu Y, Bhangale T, Graham RR, Huttenlocher J, Bjornsdottir G, Andreassen OA, Jönsson EG, et al (2012) A mutation in APP protects against Alzheimer's disease and age-related cognitive decline. Nature 488: 96-99

Kennedy ME, Stamford AW, Chen X, Cox K, Cumming JN, Dockendorf MF, Egan M, Ereshefsky L, Hodgson RA, Hyde LA, Jhee S, Kleijn HJ, Kuvelkar R, Li W, Mattson BA, Mei H, Palcza J, Scott JD, Tanen M, Troyer MD, et al (2016) The BACE1 inhibitor verubecestat (MK-8931) reduces CNS $\beta$-amyloid in animal models and in Alzheimer's disease patients. Sci Transl Med 8: 363 ra150

Kimura R, Devi L \& Ohno M (2010) Partial reduction of BACE1 improves synaptic plasticity, recent and remote memories in Alzheimer's disease transgenic mice. J. Neurochem. 113: 248261

Knopman DS (2019) Lowering of Amyloid-Beta by $\beta$-Secretase Inhibitors - Some Informative Failures. N. Engl. J. Med. 380: 1476-1478

LeWitt PA, Rezai AR, Leehey MA, Ojemann SG, Flaherty AW, Eskandar EN, Kostyk SK, 
bioRxiv preprint first posted online Jul. 13, 2019; doi: http://dx.doi.org/10.1101/698506. The copyright holder for this preprint

Thomas K, Sarkar A, Siddiqui MS, Tatter SB, Schwalb JM, Poston KL, Henderson JM, Kurlan RM, Richard IH, Van Meter L, Sapan CV, During MJ, Kaplitt MG, et al (2011) AAV2-GAD gene therapy for advanced Parkinson's disease: a double-blind, sham-surgery controlled, randomised trial. The Lancet Neurology 10: 309-319

Li T, Bourgeois J-P, Celli S, Glacial F, Le Sourd A-M, Mecheri S, Weksler B, Romero I, Couraud P-O, Rougeon F \& Lafaye P (2012) Cell-penetrating anti-GFAP VHH and corresponding fluorescent fusion protein VHH-GFP spontaneously cross the blood-brain barrier and specifically recognize astrocytes: application to brain imaging. FASEB J. 26: 39693979

Li T, Vandesquille M, Koukouli F, Dudeffant C, Youssef I, Lenormand P, Ganneau C, Maskos U, Czech C, Grueninger F, Duyckaerts C, Dhenain M, Bay S, Delatour B \& Lafaye P (2016) Camelid single-domain antibodies: A versatile tool for in vivo imaging of extracellular and intracellular brain targets. $J$ Control Release 243: 1-10

Li T, Wen H, Brayton C, Laird FM, Ma G, Peng S, Placanica L, Wu TC, Crain BJ, Price DL, Eberhart CG \& Wong PC (2007) Moderate Reduction of $\gamma$-Secretase Attenuates Amyloid Burden and Limits Mechanism-Based Liabilities. J. Neurosci. 27: 10849-10859

Mahajan SP, Meksiriporn B, Waraho-Zhmayev D, Weyant KB, Kocer I, Butler DC, Messer A, Escobedo FA \& DeLisa MP (2018) Computational affinity maturation of camelid singledomain intrabodies against the nonamyloid component of alpha-synuclein. Sci Rep 8: 17611

Maloney JA, Bainbridge T, Gustafson A, Zhang S, Kyauk R, Steiner P, van der Brug M, Liu Y, Ernst JA, Watts RJ \& Atwal JK (2014) Molecular mechanisms of Alzheimer disease protection by the A673T allele of amyloid precursor protein. J. Biol. Chem. 289: 30990-31000

McConlogue L, Buttini M, Anderson JP, Brigham EF, Chen KS, Freedman SB, Games D, Johnson-Wood K, Lee M, Zeller M, Liu W, Motter R \& Sinha S (2007) Partial reduction of BACE1 has dramatic effects on Alzheimer plaque and synaptic pathology in APP Transgenic Mice. J. Biol. Chem. 282: 26326-26334

Ou-Yang M-H, Kurz JE, Nomura T, Popovic J, Rajapaksha TW, Dong H, Contractor A, Chetkovich DM, Tourtellotte WG \& Vassar R (2018) Axonal organization defects in the hippocampus of adult conditional BACE1 knockout mice. Sci Transl Med 10: 459

Pain C, Dumont J \& Dumoulin M (2015) Camelid single-domain antibody fragments: Uses and prospects to investigate protein misfolding and aggregation, and to treat diseases associated with these phenomena. Biochimie 111: 82-106

Panza F, Solfrizzi V, Imbimbo BP \& Logroscino G (2014) Amyloid-directed monoclonal antibodies for the treatment of Alzheimer's disease: the point of no return? Expert Opin Biol Ther 14: 1465-1476 
bioRxiv preprint first posted online Jul. 13, 2019; doi: http://dx.doi.org/10.1101/698506. The copyright holder for this preprint

Pigoni M, Wanngren J, Kuhn P-H, Munro KM, Gunnersen JM, Takeshima H, Feederle R, Voytyuk I, De Strooper B, Levasseur MD, Hrupka BJ, Müller SA \& Lichtenthaler SF (2016) Seizure protein 6 and its homolog seizure 6-like protein are physiological substrates of BACE1 in neurons. Mol Neurodegener 11: 67

Rajapaksha TW, Eimer WA, Bozza TC \& Vassar R (2011) The Alzheimer's $\beta$-secretase enzyme BACE1 is required for accurate axon guidance of olfactory sensory neurons and normal glomerulus formation in the olfactory bulb. Mol Neurodegener 6: 88

Sannerud R, Declerck I, Peric A, Raemaekers T, Menendez G, Zhou L, Veerle B, Coen K, Munck S, De Strooper B, Schiavo G \& Annaert W (2011) ADP ribosylation factor 6 (ARF6) controls amyloid precursor protein (APP) processing by mediating the endosomal sorting of BACE1. Proc. Natl. Acad. Sci. U.S.A. 108: E559-568

Saraiva J, Nobre RJ \& Pereira de Almeida L (2016) Gene therapy for the CNS using AAVs: The impact of systemic delivery by AAV9. J Control Release 241: 94-109

Sasaguri H, Nilsson P, Hashimoto S, Nagata K, Saito T, Strooper BD, Hardy J, Vassar R, Winblad B \& Saido TC (2017) APP mouse models for Alzheimer's disease preclinical studies. The EMBO Journal 36: 2473-2487

Steeland S, Vandenbroucke RE \& Libert C (2016) Nanobodies as therapeutics: big opportunities for small antibodies. Drug Discovery Today 21: 1076-1113

Timmers M, Streffer JR, Russu A, Tominaga Y, Shimizu H, Shiraishi A, Tatikola K, Smekens P, Börjesson-Hanson A, Andreasen N, Matias-Guiu J, Baquero M, Boada M, Tesseur I, Tritsmans L, Van Nueten L \& Engelborghs S (2018) Pharmacodynamics of atabecestat (JNJ54861911), an oral BACE1 inhibitor in patients with early Alzheimer's disease: randomized, double-blind, placebo-controlled study. Alzheimers Res Ther 10: 85

Trapani I, Colella P, Sommella A, Iodice C, Cesi G, de Simone S, Marrocco E, Rossi S, Giunti M, Palfi A, Farrar GJ, Polishchuk R \& Auricchio A (2014) Effective delivery of large genes to the retina by dual AAV vectors. EMBO Mol Med 6: 194-211

Vassar R, Bennett BD, Babu-Khan S, Kahn S, Mendiaz EA, Denis P, Teplow DB, Ross S, Amarante P, Loeloff R, Luo Y, Fisher S, Fuller J, Edenson S, Lile J, Jarosinski MA, Biere AL, Curran E, Burgess T, Louis JC, et al (1999) Beta-secretase cleavage of Alzheimer's amyloid precursor protein by the transmembrane aspartic protease BACE. Science 286: 735-741

Verhelle A, Nair N, Everaert I, Van Overbeke W, Supply L, Zwaenepoel O, Peleman C, Van Dorpe J, Lahoutte T, Devoogdt N, Derave W, Chuah MK, VandenDriessche T \& Gettemans J (2017) AAV9 delivered bispecific nanobody attenuates amyloid burden in the gelsolin amyloidosis mouse model. Hum. Mol. Genet. 26: 1353-1364 
bioRxiv preprint first posted online Jul. 13, 2019; doi: http://dx.doi.org/10.1101/698506. The copyright holder for this preprint

Vincke C, Loris R, Saerens D, Martinez-Rodriguez S, Muyldermans S \& Conrath K (2009) General strategy to humanize a camelid single-domain antibody and identification of a universal humanized nanobody scaffold. J. Biol. Chem. 284: 3273-3284

Voytyuk I, De Strooper B \& Chávez-Gutiérrez L (2018a) Modulation of $\gamma$ - and $\beta$-Secretases as Early Prevention Against Alzheimer's Disease. Biol. Psychiatry 83: 320-327

Voytyuk I, Mueller SA, Herber J, Snellinx A, Moechars D, van Loo G, Lichtenthaler SF \& De Strooper B (2018b) BACE2 distribution in major brain cell types and identification of novel substrates. Life Sci Alliance 1: e201800026

Wang Q, Delva L, Weinreb PH, Pepinsky RB, Graham D, Veizaj E, Cheung AE, Chen W, Nestorov I, Rohde E, Caputo R, Kuesters GM, Bohnert T \& Gan L-S (2018) Monoclonal antibody exposure in rat and cynomolgus monkey cerebrospinal fluid following systemic administration. Fluids Barriers CNS 15: 10

Wang W, Liu Y \& Lazarus RA (2013) Allosteric inhibition of BACE1 by an exosite-binding antibody. Current Opinion in Structural Biology 23: 797-805

Wilhelm BG, Mandad S, Truckenbrodt S, Kröhnert K, Schäfer C, Rammner B, Koo SJ, Claßen GA, Krauss M, Haucke V, Urlaub H \& Rizzoli SO (2014) Composition of isolated synaptic boutons reveals the amounts of vesicle trafficking proteins. Science 344: 1023-1028

Willem M, Garratt AN, Novak B, Citron M, Kaufmann S, Rittger A, DeStrooper B, Saftig P, Birchmeier C \& Haass C (2006) Control of peripheral nerve myelination by the beta-secretase BACE1. Science 314: 664-666

Wu Z, Yang H \& Colosi P (2010) Effect of genome size on AAV vector packaging. Mol. Ther. 18: $80-86$

Yan R \& Vassar R (2014) Targeting the $\beta$ secretase BACE1 for Alzheimer's disease therapy. Lancet Neurol 13: 319-329

Ye X, Feng T, Tammineni P, Chang Q, Jeong YY, Margolis DJ, Cai H, Kusnecov A \& Cai Q (2017) Regulation of Synaptic Amyloid- $\beta$ Generation through BACE1 Retrograde Transport in a Mouse Model of Alzheimer's Disease. J. Neurosci. 37: 2639-2655

Zafir-Lavie I, Sherbo S, Goltsman H, Badinter F, Yeini E, Ofek P, Miari R, Tal O, Liran A, Shatil T, Krispel S, Shapir N, Neil GA, Benhar I, Panet A \& Satchi-Fainaro R (2018) Successful intracranial delivery of trastuzumab by gene-therapy for treatment of HER2positive breast cancer brain metastases. J Control Release 291: 80-89

Zhou L, Chávez-Gutiérrez L, Bockstael K, Sannerud R, Annaert W, May PC, Karran E \& De 
bioRxiv preprint first posted online Jul. 13, 2019; doi: http://dx.doi.org/10.1101/698506. The copyright holder for this preprint

(which was not peer-reviewed) is the author/funder, who has granted bioRxiv a license to display the preprint in perpetuity.

It is made available under a CC-BY-NC-ND 4.0 International license.

Anti-BACE1 VHH lowers $A \beta$ in an AD model

Strooper B (2011) Inhibition of beta-secretase in vivo via antibody binding to unique loops (D and F) of BACE1. J. Biol. Chem. 286: 8677-8687

Zhu K, Xiang X, Filser S, Marinković P, Dorostkar MM, Crux S, Neumann U, Shimshek DR, Rammes G, Haass C, Lichtenthaler SF, Gunnersen JM \& Herms J (2018) Beta-Site Amyloid Precursor Protein Cleaving Enzyme 1 Inhibition Impairs Synaptic Plasticity via Seizure Protein 6. Biol. Psychiatry 83: 428-437 
Figure 1. Rincon MY., Zhou L., et al.

A

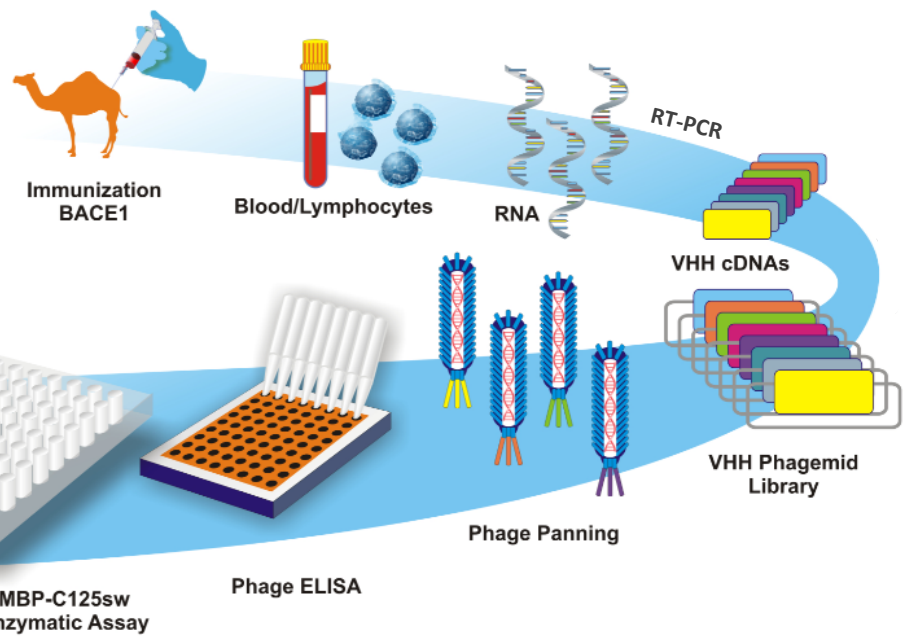

B

MBP-C125APPsw BACE1 enzymatic assay

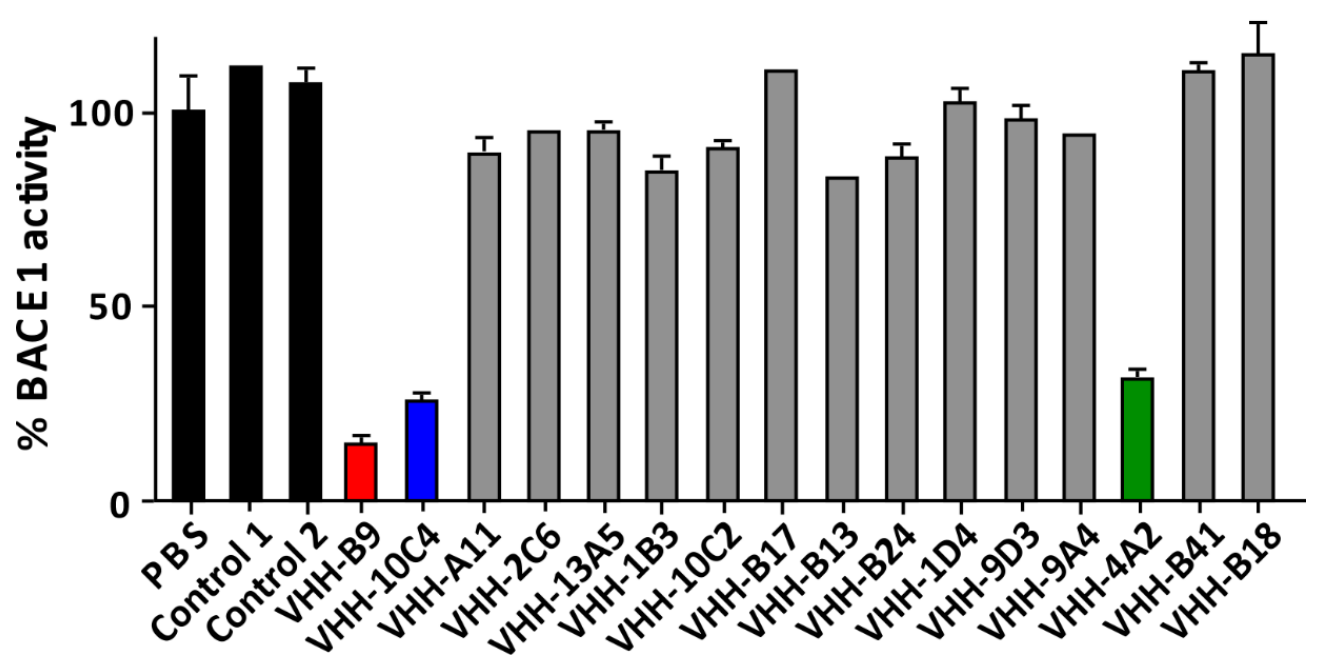

C

MBP-C125APPsw BACE1 enzymatic assay

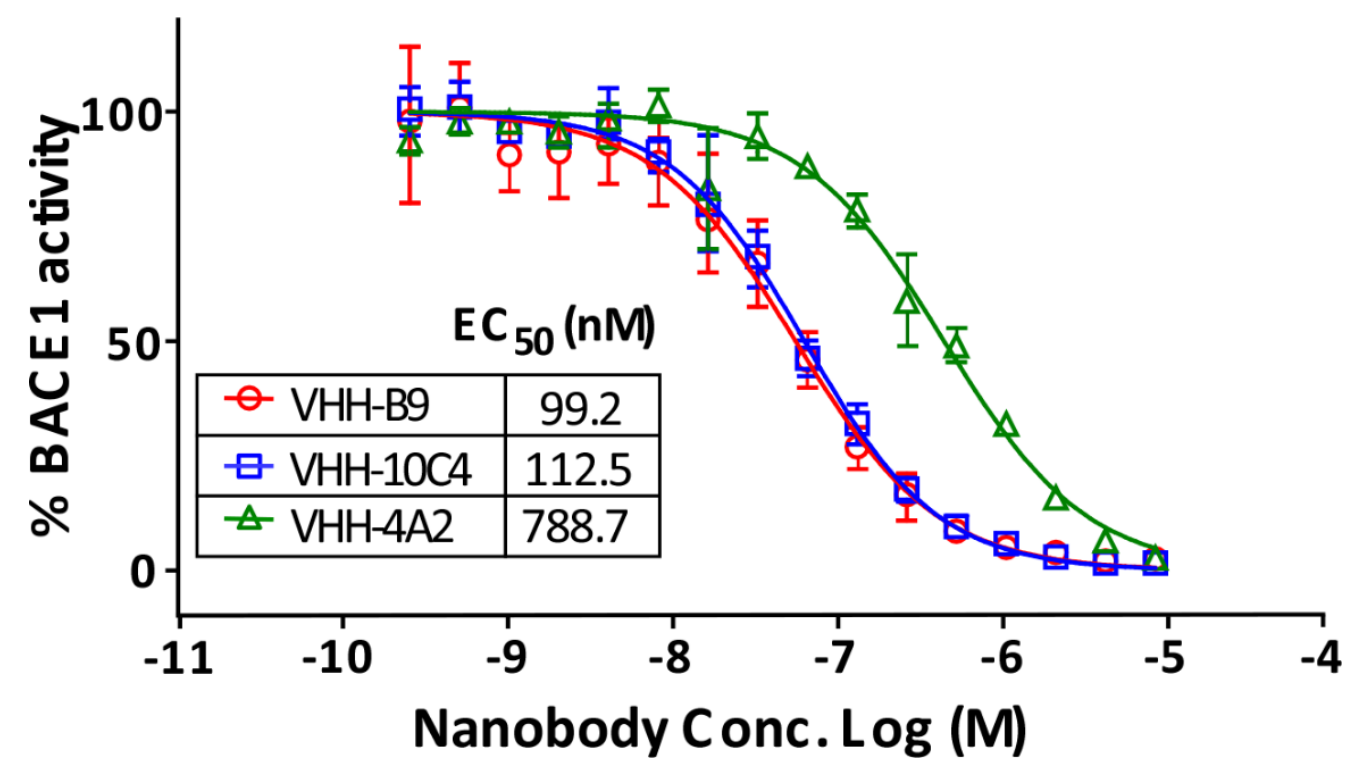


D

Binding affinities of selected VHH to human BACE1

\begin{tabular}{ccccc}
\hline VHH & $\mathbf{p H}$ & $\mathbf{k}_{\text {on }}\left(\mathbf{M}^{-1} \mathbf{s}^{-1}\right)$ & $\mathbf{k}_{\text {off }}\left(\mathbf{s}^{-1}\right)$ & $\mathbf{K}_{\mathbf{D}}(\mathbf{n M})$ \\
\hline \multirow{2}{*}{ VHH-B9 } & 7.0 & $2.67 \times 10^{5}$ & $9.80 \times 10^{-4}$ & 3.7 \\
& 4.5 & $6.62 \times 10^{5}$ & $1.30 \times 10^{-4}$ & 1.9 \\
\hline \multirow{2}{*}{ VHH-10C4 } & 7.0 & $1.06 \times 10^{5}$ & $7.92 \times 10^{-3}$ & 74.7 \\
& 4.5 & $4.51 \times 10^{5}$ & $1.25 \times 10^{-2}$ & 27.7 \\
\hline \multirow{2}{*}{ VHH-4A2 } & 7.0 & $4.79 \times 10^{5}$ & $2.31 \times 10^{-2}$ & 48.2 \\
& 4.5 & $3.97 \times 10^{5}$ & $8.41 \times 10^{-3}$ & 21.2 \\
\hline
\end{tabular}

E

Binding affinities of VHH-B9 to BACE1 vs. BACE2

\begin{tabular}{ccccc}
\hline & Conc. (nM) & $\mathbf{k}_{\text {on }}\left(\mathbf{M}^{-1} \mathbf{s}^{-1}\right)$ & $\mathbf{k}_{\text {off }}\left(\mathbf{s}^{-1}\right)$ & $\mathrm{K}_{\mathrm{D}}(\mathrm{nM})$ \\
\hline mBACE1 $^{*}$ & 100 & $2.24 \times 10^{5}$ & $7.20 \times 10^{-4}$ & 3.2 \\
hBACE1 $^{*}$ & 100 & $1.53 \times 10^{5}$ & $4.43 \times 10^{-4}$ & 2.9 \\
mBACE2 & 100 & $\mathrm{NR}$ & $\mathrm{NR}$ & $\mathrm{NR}^{*}$ \\
\hline
\end{tabular}


Figure 3. Rincon MY., Zhou L., et al.
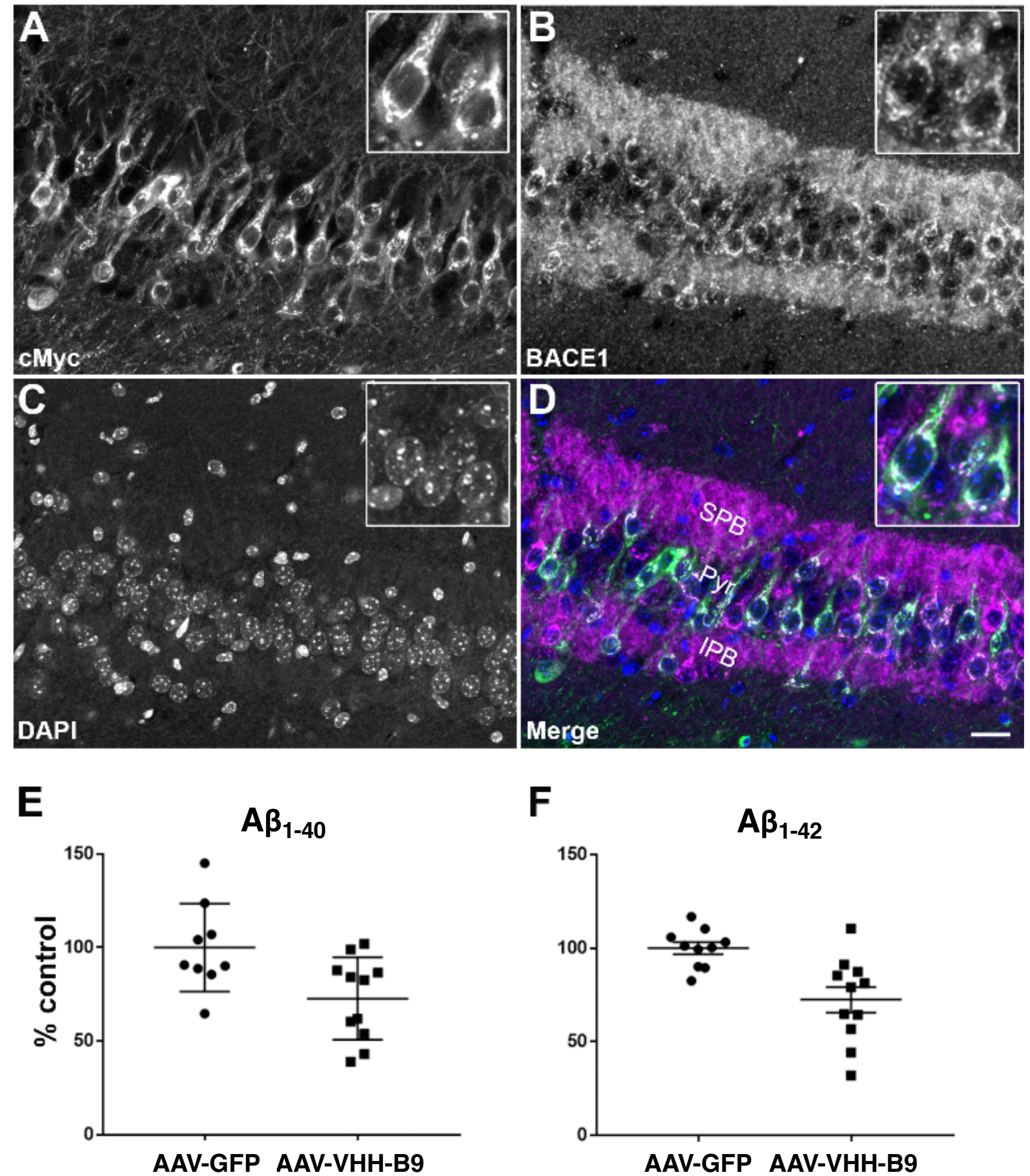